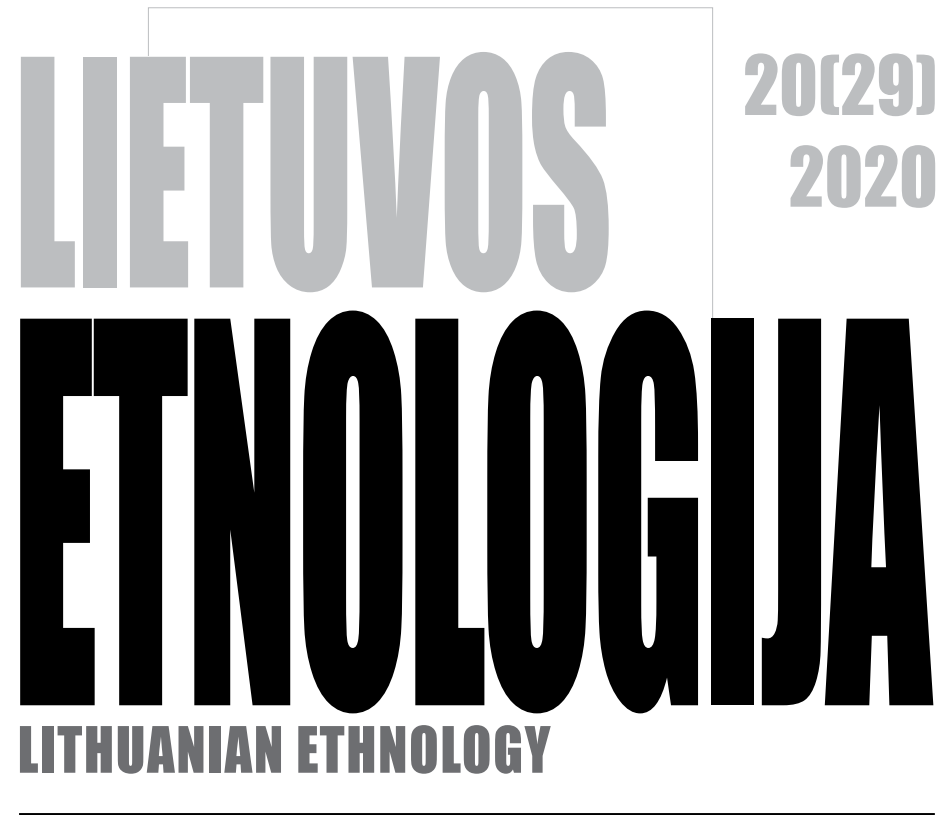

STUDIES IN SOCIAL ANTHROPOLOGY AND ETHNOLOGY

LIETUVOS ISTORIJOS INSTITUTAS

LITHUANIAN INSTITUTE OF HISTORY

VILNIUS 2020 
Lietuvos etnologija: socialines antropologijos ir etnologijos studijos - mokslinis etnologijos ir socialinès ir kultūrinès antropologijos žurnalas. Jame spausdinami recenzuojami straipsniai, konferenciju pristatymai, knygu recenzijos ir apžvalgos, kurių temos pirmiausia apima Lietuvą ir Vidurio/Rytų Europą. Žurnalas pristato mokslo aktualijas ir skatina teorines bei metodines diskusijas. Tekstai skelbiami lietuvių arba anglų kalba.

Lithuanian Ethnology: Studies in Social Anthropology and Ethnology - is a peer reviewed journal of ethnology and social and cultural anthropology. It publishes articles, conference presentations, book reviews and review articles, which may be in Lithuanian or English, primarily focused on Lithuania, Central and Eastern Europe. The journal represents current debates and engages in methodological discussions.

\section{REDAKCINĖ KOLEGIJA / EDITORIAL BOARD}

Vytis Čiubrinskas (vyriausiasis redaktorius / Editor-in-Chief)

Vytauto Didžiojo universitetas / Vytautas Magnus University, Kaunas, Lithuania

Auksuolè Čepaitienè

Lietuvos istorijos institutas / Lithuanian Institute of History, Vilnius, Lithuania

Jonathan Friedman

Kalifornijos universitetas / University of California, San Diego, USA

Chris Hann

Maxo Plancko socialinés antropologijos institutas / Max Planck Institute for Social Anthropology,

Haale / Saale, Germany

Jonathan Hill

Pietu Ilinojaus universitetas / Southern Illinois University, Carbondale, USA

Neringa Klumbytè

Majamio universitetas / Miami University, Ohio, USA

Ullrich Kockel

Heriot-Watt universitetas / Heriot-Watt University, Edinburgh, UK

Orvar Löfgren

Lundo universitetas / Lund University, Sweden

Jonas Mardosa

Vytauto Didžiojo universitetas / Vytautas Magnus University, Kaunas, Lithuania

Žilvytis Šaknys

Lietuvos istorijos institutas / Lithuanian Institute of History, Vilnius, Lithuania

REDAKCINĖS KOLEGIJOS SEKRETORĖ / EDITORIAL ASSISTANT

Danguolè Svidinskaite

Lietuvos istorijos institutas / Lithuanian Institute of History, Vilnius, Lithuania

Leidyklos adresas / Address of the Publisher: Redakcinès kolegijos kontaktai / Editorial inquiries: Lietuvos istorijos institutas

Kražių g. 5, LT-01108 Vilnius

El. paštas / E-mail: etnolog@istorija.lt

$<w w w . i s t o r i j a . l t>$

Žurnalas registruotas / The Journal indexed in:

European Reference Index for the Humanities (ERIH)

EBSCO Publishing: Academic Search Complete, Academic Search Ultimate, Energy and Power Source, SocINDEX with Full Text, Sociology Source Ultimate

Modern Language Association (MLA) International Bibliography

Leidybą finansavo Lietuvos mokslo taryba pagal Valstybinę lituanistinių tyrimų ir sklaidos 2016-2024 metų programą (Sutartis Nr. S-LIP-19-58) 


\title{
„Visi nori to savo versliuko“: posovietinè deindustrializacija, darbas ir pragyvenimo būdai Marijampolèje
}

\author{
Aušra Teleiš̀
}

Straipsnyje, remiantis Marijampolès mieste atliktu lauko tyrimu, keliamas klausimas, kaip Marijampolèje, kuri sovietmečiu plètota kaip industrinis miestas, buvo pragyventi deindustrializacijos, nulemtos ekonominio posūkio iš sovietinės planinės ekonomikos i rinkos ekonomika, sukelti iššūkiai. Analizuojami aspektai, lèmę individualių veiklų susikūrimą ir plètojimą; kaip plètojamas lanksčiai organizuojamas darbas ir jo įvairovė kūrè naujas darbo vietas bei transformavo buvusio sovietinio industrinio miesto vietas; darbo sampratos pokyčiai. Straipsnyje atskleidžiama, jog deindustrializacijos sukelti iššūkiai buvo išgyventi pasitelktus verslumą ir neformalius pragyvenimo būdus: įvairią prekybą ir paslaugų teikima, turinčius polinkị plèstis, įtraukti artimus asmenis ir formuoti naujas struktūras.

Raktiniai žodžiai: darbas, pragyvenimo būdai, verslas, posovietine deindustrializacija, Marijampole.

This paper asks how people made their livings in the former Soviet industrial city of Marijampole during the crisis that was caused by the deindustrialization associated with the transition from a centrally planned economy to a market economy. It analyses aspects that helped to develop and include people in means of livelihood; the ways in which work activities produce new workplaces and have an impact on the transformation of places in Marijampole; and transformations of the concept of work. It shows that means of livelihood that are used during a work crisis tend to expand, involve others, and form structures.

Key words: work, means of livelihood, business, post-Soviet deindustrialization, Marijampole.

Aušra Teleišè, Lietuvos istorijos institutas, Etnologijos ir antropologijos skyrius, Kražiu g. 5, LT-01108 Vilnius, el. paštas: ausra.teleise@gmail.com 


\section{Ivadas}

Pramonès įmonių apimčių mažèjimas, decentralizavimas ar uždarymas - tai kurị laiką ìvairiose industrializuotose šalyse vykstantys ekonominiai reiškiniai, kurie siejami su deindustrializacija, pakeitusia pramonės darbininkų gyvenimo būdą bei kasdienybę ir sukèlusia darbo krizę, kuri šiame straipsnyje suvokiam kaip nestabilumas darbovietejje, nedarbas, darbo vietų praradimas, pajamų mažejjimas ar neišmokami atlyginimai. Jeffersonas Cowie ir Josephas Heathcottas pažymi, jog deindustrializacija - socialiai sudètingas, geografiškai įvairus ir politiškai stulbinantis procesas (Cowie, Heathcott 2003: 2). Šis procesas pasižymëjo specifiniais savitumais Lietuvoje ir kitose posovietinėse šalyse, kur deindustrializacija buvo susijusiu su politiniais sprendimais ir staigiu ekonominiu posūkiu iš planinès ekonomikos i rinkos ekonomiką. Michaelis Burawoy ir Katherine Verdery akcentuoja, kad šie ekonominiai pokyčiai - tai daugialypis procesas, galintis sukelti skirtingus rezultatus ir reakcijas (Burawoy, Verdery 1999: 15).

Deindustrializacija, nulemta ekonominio posūkio ir politinių sprendimu, tai konkretus istorinis laikotarpis, apimantis sovietinės ekonomikos, pramonès imonių sisteminius ir struktūrinius pasikeitimus, naujų ekonominių vietų ir veiklų susikūrima, bet taip pat individualiai išgyventas procesas ir įvykiai, kurių metu vyko esminiai pokyčiai, palietę žmonių pragyvenimą ir darbą. Kitaip tariant, posovietinės deindustrializacijos sukeltas nesaugumas - tai įvairiose vietose - regionuose, valstybėse ar miestuose - skirtingai išgyventos patirtys. Kadangi atliekant Alytaus miesto tyrimus (žr. Jurčikonytė 2016; Jurčikonytė 2017) greta atsirasdavo ir Marijampolės miestas kaip panašios sovietinės industrializacijos ir urbanizacijos atvejis, iškilo poreikis pasižiūrèti, kokie procesai vyksta ir kaip jie išgyvenami miesto gyventoju kitame sovietiniame industriniame regioniniame centre Marijampolejje. Straipsnyje ir keliamas klausimas, kaip žmonès, dirbę už fiksuotą pastovu atlyginimą ${ }^{1}$, išgyveno posovietinès deindustrializacijos iššūkius Marijampolès mieste. Kokius pragyvenimo būdus, kuriais stengtasi iqveikti deindustrializacijos sukeltą darbo krizę - užsidirbti pragyvenimui ar igyti papildomų pajamų - plètotojo marijampoliečiai?

Pasitelkiant antropologinę prieigą siekiama atskleisti, kaip Marijampolės miesto gyventojai pergyveno posovietinès deindustrializacijos sukeltą darbo krizę. Tyrime akcentuojama socialinių santykių dinamika, pragyvenimo būdų formalizavimas, darbo sampratos ir miesto vietu pokyčiai. Siekiant tikslo iškeliami uždaviniai: atskleisti, kaip deindustrializacijos metu plètotos žmonių praktikos perkūrè Marijampolès miestą pateikiant vienos pagrindinių Marijampolès gatvių - Kauno gatvès - šiandieninį vaizdą; alternatyvių darbui už fiksuotą pas-

\footnotetext{
${ }^{1}$ Stabilios, kas mėnesi gaunamos pajamos, kurių dydis yra žinomas (fiksuoti tarifiniai įainiai arba mènesinis atlyginimas).
} 
tovų atlyginimą pragyvenimo būdų atsiradimo ir formavimosi aspektus; pragyvenimo būdų tapimą formaliomis darbinèmis veiklomis, kuriančiomis naujas darbo vietas ir struktūras; esminius individualių veiklų ir verslumo sampratos pokyčio aspektus, ivykusius po Lietuvos nepriklausomybės atgavimo. Straipsnyje pristatomas marijampoliečiu požiūris, veiklos ir patirtys, igytos išgyvenant finansinius sunkumus, atsiradusius dèl pokyčių pramonės i̇monėse. Kadangi pateikejjai šias patirtis sieja su politiniais ivvykiais, deindustrializacijos sukelti iššūkiai ir darbo krizè pateikiama kaip situacija, susidariusi po Lietuvos nepriklausomybès atgavimo.

Tyrimo empirini pagrindą sudaro $2018 \mathrm{~m}$. lapkričio-2019 m. gruodžio mèn. vykdytas lauko tyrimas Marijampolëje. Tyrime, kurio metu siekta pažinti dabartinę Marijampolę - sovietinį industrinį miesta jame vykstančius socialinius ir kultūrinius procesus, praeities ìvykiai ir procesai interpretuojami iš šiandieninės perspektyvos. Atkreiptinas dèmesys, jog miestas, būdamas nuolatinių pokyčių vieta, kurioje veikia sudetinga, heterogeninè visuomenė, anot Kelvino Low, kultūrines išraiškas ir praktikas integruoja i savo gyvenimą: statytinę aplinką ir žmogiškąsias patirtis bei atminti (Low 2015: 296). Taigi miesto etnografinis pažinimas neapsiriboja tik žmonių pasakojimais, svarbu miestą patirti ir pamatyti (Barthes 1982; Low 2015). Būtent vaikščiojimo etnografija suvokiama kaip paprasčiausias būdas įsitraukti i miesto gyvenima, perskaityti vietos naratyvus ir patirtis (de Certeau 1988; Wunderlich 2008). Išskiriamos dvi vaikščiojimo mieste formos: tyrëjas vaikšto vienas - tyrëjo sensorinės ir kūniškos patirtys, igytos einant miesto gatvėmis, naviguojant tarp skirtingų objektų, dalyvaujant miesto ivykiuose, miesto ar įvairių jo dalių ritmo pajautimas yra esminis dalykas; vaikščiojama kartu su pateikejjais - akcentuojamos pateikëjų patirtys ir pasakojimai, atsiskleidžiantys judant tam tikromis vietomis (Edensor 2010; Low 2015; Ingold, Vergunst 2016). Tyrimo metu Marijampolèje vaikščiojama be pateikëjų, tačiau igytos patirtys reikšmingai papildo pateikèju pasakojimus.

Siekiant orientuotis Marijampolès mieste, lauko tyrimas pradètas nuo suplanuotų vaikščiojimu pagrindinėmis miesto gatvėmis, aplankant įvairias miesto dalis, vèliau - pateikèjų minimas miesto vietas, jose praleidžiant daugiausia laiko. Vaikščiojimų metu siekiama pažinti pateikejju pasakojimuose atsiskleidžianti miesta, taip pat stebima, ką žmonès veikia įvairiose miesto dalyse, gatvėse, parkuose ir aikštėse, kurios miesto vietos pritraukia daugiausia žmoniư, kaip atrodo pastatai ir kiti objektai (vaikų žaidimo aikštelès, suoliukai, reklaminiai, turistiniai stendai, autobusų stotelès), kokie pastatai ar kiti objektai aplink juos, atkreiptas dèmesys i mieste esančius užrašus. Marijampolëje vaikščiota daug kartų, visais metų laikais, įvairiomis valandomis.

Tyrimo metu atliekant pusiau struktūruotus interviu bendrauta su 39 vyrais ir moterimis, kurie gyvena Marijampolëje. Pagrindinis pateikèjų atrankos 
kriterijus - asmenys sovietmečiu dirbę pramonès įmonėse, tačiau pateikëjams i pokalbi itraukiant šeimos narius, kolegas ar draugus, pasiūlant susitikti su žmonèmis, kurie Marijampolëje gyvena ilgiau, užsièmė automobilių prekyba, dirbo kioskeliuose, bei siekiant pažinti Marijampolės miestą ir lankantis miestą reprezentuojančiose įstaigose, buvo bendrauta su i̇vairaus amžiaus ir visokias pareigas (darbininkais, gamyklų darbuotojais, mokytojais, muziejininkais, gydytojais, kultūros darbuotojais) ejjusiais asmenimis. Dauguma pateikëju - vidutinio ir vyresnio (1940-1968 m. gimimo) amžiaus žmonès. Pateikejjų posovietinės patirtys skirtingos: buvo atleisti, savo iniciatyva išejo iš darbovietės ar išlaikè darbo vietą. Bendraujant su pateikejjas paaiškëjo, kad asmenys, tiesiogiai nesusiję su pramonės įmonių veikla, taip pat susidūrè su deindustrializacijos iššūkiais, pavyzdžiui, suprastėjusi finansinè padètis sutuoktiniui netekus darbo. Galima išskirti tris pateikẻjų grupes, kurie ėmėsi aktyvių veiksmų siekdami pagerinti ekonominę situaciją: 1) asmenys, kuriems nepavyko greitai susirasti darbo vietos ir îsidarbinti; 2) turèjo apmokamą darba, bet išgyveno finansinius sunkumus; 3) norèjo daugiau užsidirbti. Šiuo metu kai kurie yra pensininkai, kiti dirba apmokamą darbą pramonės įmonėse ar kitose i̇staigose, tik vienas ịkūręs i̇monę. Kadangi tyrimo metu siekta pažinti šiandienini miestą ir miestiečiu patirtis, igytas po Sovietų Sajungos iširimo, pateikejjų klausta, kaip pasikeite kasdienybè ir miestas, domėtasi gyvenimu Marijampolëje. Pusiau struktūruoti interviu vyko pateikejų namuose, darbovietėse ar ju pasirinktose viešose miesto vietose. Atlikti 8 atsitiktiniai trumpi pasikalbejjimai su mieste sutiktais žmonėmis: laukiant autobuso, lankantis miesto renginiuose. Pokalbiuose reaguojama į tuo metu buvusią aplinką. Nors tyrimas apima platesni klausimą - šiandieninę Marijampolę ir joje vykstančius kultūrinius procesus, tačiau darbo tema - darboviečių keitimas, darbinių veiklų ir santykių dinamika - pasikartodavo ir iškildavo pateikejjų pasakojimuose.

\section{Teorinis pagrindas}

Antropologai darbą bendriausia prasme suvokia kaip esminę gyvenimo dali, kurios pagrindu organizuojamas gyvenimas (Strümpell 2017: 5) ir visuomenè (Kesküla 2018). Darbo principų keitimasis, Eevos Keskülos teigimu, tiesiogiai susijęs su gyvensenos ir vietos transformacijomis, o industrializacija ir deindustrializacija yra erdvės ir laiko struktūrinimo būdai (Kesküla 2018).

Industrializacija ittvirtino darbo sampratą paremtą aiškia erdvės ir laiko atskirtimi: darbo vieta atskirta nuo „namu“, darbo valandos - nuo poilsio (Strümpell 2017; Kesküla 2018). Tokia situacija sukūrè sutarties principu paremtus santykius tarp darbuotojo ir darbdavio, anot Jonathano Parry, žinomus kaip „standartinio i̇darbinimo kontraktas“ (Parry 2018: 2). Taigi buvo suformuota pramonės darbininko priklausomybė nuo darbo už fiksuotą pastovų atlyginimą, 
kai, Stuarto Plattnerio teigimu, darbininkas parduoda savo darbą kaip prekę, kad pragyventų: issigytų maisto, drabužių, būstą ir kitką (Plattner 1989: 382). Antropologai išryškina, kad industrializacija darbą susiejo su tokiomis sąvokomis kaip visa darbo diena, stabilus ir pastovus užimtumas, užmokestis, socialinė apsauga ir gerovè, profsajungos, darbas didelèse įmonèse (Strümpell 2017: 7; Harvey, KrohnHansen 2018: 13; Parry 2018: 2). Industrializacijos metu susiformavo suvokimas, kad darbas didelëje pramonės įmonèje suteikia saugumo ir užtikrina ateitį.

Deindustrializacijos procesas transformavo industrializacijos metu susiformavusią darbo samprata, miesto vietas: blogejjanti pramonės rajonų būklè, miesto erdvėse atsirandančios neformalios ekonominès veiklos (Jaffe, de Koning 2016), ir perstruktūrizavo darbinius santykius. Deindustrializacijos sukelti reiškiniai - masinis darbo praradimas, darbo vietų už fiksuotą pastovų atlyginimą mažèjimas suvokiami kaip dramatiškas darbo pokytis (Strangleman 2007: 81) ir gyvensenos iššūkis. Besikeičiančios darbo ir gyvensenos aplinkybès, anot Michalo Buchowskio, priverčia žmones plètoti naujas veiklos formas (Buchowski 2004: 181). Negalèdami rasti reguliaraus, samdomo darbo, žmonès improvizuoja ir plètoja neformalias veiklas ${ }^{2}$, apibrèžiamas per "savęs įdarbinimą" - individualią veiklą (Smith 1989: 301-302), ar praktikas, duodančias pajamu, bet nesusijusias su formaliu apmokamu darbu ir socialinėmis garantijomis (Portes, Walton 1981: 87). Būtent samdomų darbuotojų, dirbančių už fiksuotą pastovų atlyginima, poreikio mažèjimas, Frances Pine teigimu, žymi lanksčiai organizuojamo darbo pradžią (Pine 2014: S96). Tradiciškai lankstus darbas siejamas su pramonès restruktūrizavimu ir darbinių santykių pasikeitimu - naujomis įdarbinimo formomis (Harvey 1990; Narotzky 2015), tačiau Jenso Kjaerulffo sudarytame straipsnių rinkinyje lankstus darbas atskleidžiamas kaip daugialypis reiškinys, apimantis darbo valandas ir organizavimą bei igūūžius, tapatumą, socialinius vaidmenis ar tinklaveiką (Kjaerulff 2015: 8-9). Kitaip tariant, lankstus darbas, kai siekiant pragyventi nesaugumą plètojamos kitokios, negu visos darbo dienos, kontraktinès darbo formos, siejamas su kultūriniais ir socialiniais procesais, transformavusiais industrializacijos sąlygomis susiformavusią gyvenseną ir tvarką. Akcentuotinas Christine J. Walley pastebejimas, jog deindustrializacijos sukeltas nesaugumas paveikia ne tik pramonès darbuotojus, bet ir visus šalies gyventojus (Walley 2013: 58). Straipsnyje deindustrializacija ir suvokiama kaip procesas, palietęs visus miesto gyventojus.

Apskritai darbas apibrėžiamas kaip darbinès pastangos, susijusios su kapitalistiniais gamybos santykiais (Narotzky 2018: 41). Socializmo laikotarpiu darbui buvo priskirtos papildamos reikšmès. Jis buvo viena pagrindinių ideologinių ir

${ }^{2}$ Antropologai praktikas, apimančias privačią gamyba, paslaugų teikimą, dèl i̇vairiu priežasčiu nepatenkančias î viešus stebëjimus, reguliavimus įvardina neformalios ekonomikos terminu (Smith 1989: 294). 
socialinių veiklų, kur darbininkas skatinamas savo darbą suvokti kaip svarbų valstybei (Shlapentokh 1989: 25; Humphrey 1995: 3). Sovietmečiu buvo itin sureikšminta darbo vieta ir asmens paruošimas jai - tai speciali profesinè veikla (Hohnen 2001: 69). Darbovietė funkcionavo kaip pagrindinis socialinės ir politinès galios centras (Verdery 1996: 206), lyg „,sala“, globojanti ir kurianti darbininkų gerovę (Nielsen 2006). Darbas sovietinëje pramonès i̇monèje ar kitoje i̇staigoje buvo ne tik stabiliu pajamu šaltinis, užtikrinta darbo vieta, bet taip pat suteikè gyvenamąji plotą, laisvalaikio užimtumą, socialini saugumą.

Posovietiniuose antropologiniuose tyrimuose darbas ir su juo susiję kultūriniai, socialiniai pokyčiai analizuojami ekonominių ir politinių transformacijų kontekste, akcentuojant (ne)prisitaikymo būdus ir strategijas. Verdery per nuosavybės teisę, socialinius tinklus ir valdžios transformacijas atskleidžia socialinius procesus posocialistineje Rumunijoje (Verdery 1996). Davidas Kideckelis tyrinejja Rumunijos angliakasių nesugebejjimą prisitaikyti prie naujos ekonominès situacijos, kai darbo vietos netekimas siejamas su gyvenimo kontrolès ir tapatumo, kuri suteikè darbas, praradimu (Kideckel 2001). Elizabeth Dunn atkreipia dèmesị i Lenkijos pramonès darbininkų lankstumą: specialybẻs keitimą kitų igūdžių igijimą siekiant išlaikyti darbo vietą privatizuojamoje gamykloje ar adaptuotis prie kapitalizmo (Dunn 2004). Caroline Humphrey atskleidžia nauju nelegalių socialinių struktūrų formavimąsi ir pasipelnymo aspekta, vykstantị prisitaikant prie rinkos ekonomikos bei pasinaudojant atsiradusiomis galimybėmis Rusijoje (Humphrey 2002). Saraha Ashwin, analizuodama Rusijos angliakasiu patirtis pažymi, jog pokyčių metu pragyvenimo būdai tampa individualizuoti, susieti su šeima ir prekyba (Ashwin 1999). Pernille Hohnen i i ivykusius pokyčius Lietuvoje žvelgia iš moralinės ekonomikos perspektyvos ir analizuoja verslumą bei prekybą turguje kaip darbo konceptualizavimo klausimą (Hohnen 2001; Hohnen 2007). Lietuvių posovietiniuose antropologiniuose tyrimuose Neringa Klumbytė atkreipia dèmesi i ryši tarp nostalgijos sovietmečiui ir darbo netekimo, finansinės padèties suprastėjimo (Klumbytė 2008). Kristina Šliavaitė akcentuoja visaginiečių požiūrị i IAE uždaryma, kuris siejamas su asmeninès ir miesto ateities neužtikrintumu, pavojumi žinomam gyvenimo būdui (Šliavaitė 2003; Šliavaitė 2010).

Posovietiniuose antropologiniuose darbo tyrimuose naujų socialinių, kultūrinių ir ekonominių struktūru atsiradimas suvokiamas kaip socialistinių patirčių, veikimo modelių ir mąstymo derinimas su rinkos ekonomikos vertybèmis. Straipsnyje laikomasi požiūrio, kad deindustrializacija posovietinėse šalyse sukèlè darbo krizę, tačiau akcentuojama, jog šiomis sąlygomis pasitelktas darbo lankstumas - „savęs įdarbinimas“, kai susikuriama darbo vieta ir asmeniškai vykdoma individuali darbinè veikla, buvo priemonè, padejusi įveikti posovietinès deindustrializacijos iššūkius. Kitaip tariant, tai pragyvenimo būdas - įvairūs veiksmai ir pastangos, kuriomis siekiama patenkinti būtiniausius poreikius, susidoroti su neaiškumu ar pasinaudoti atsiradusiomis galimybėmis (Long 2005: 194). 


\section{Tyrimo vieta: Marijampolès miestas}

Marijampolè (sovietmečiu Kapsukas) - pietvakarių Lietuvoje abipus Šešupės upès išsidèstęs miestas, esantis netoli sienos su Lenkija ir Kaliningrado sritimi. 2019 m. mieste gyveno apie 35 tūkst. gyventojų (Lietuvos gyventojai 2019). Jau tarpukariu, kai Lietuvos ateitis sieta su išplètota pramone (Drėmaitė 2016: 49), Marijampoleje steigti „Lino“, baldų, „Šešupès“ audimo fabrikai. Atsižvelgiant i geografines ir susisiekimo ypatybes, $1931 \mathrm{~m}$. pastatytas cukraus fabrikas, kurio atidarymas tapo svarbiu miesto įvykiu (Drėmaitė 2016: 155-160). Miesto industrializacija itin suaktyvëjo sovietmečiu, $1964 \mathrm{~m}$. suplanavus Marijampolę plètoti kaip vieną iš penkių pramoninių regioninių centrų Lietuvoje ir numačius pramonės darbuotojų skaičiaus 1980 m. išaugimą iki 12 tūkst. (KRVA F R-1705, b. 4, 1. 129 - Kauno regioninis valstybės archyvas, fondas R-1705, byla 4, lapas 129). Taigi sovietmečiu išplèsti tarpukariu i̇steigti fabrikai, pastatytos naujos pramonės i̇monės: Kapsuko TSRS 50-mečio maisto pramonės automatu gamybinis susivienijimas, Putliųju verpalų fabrikas, Pieno konservų kombinatas, Autoremonto gamykla, Grūdų produktų kombinatas, Gelžbetonio konstrukciju gamykla. Pramonès i̇monès taip pat prisidejo prie tolesnès miesto plètros: statė daugiabučius, rẻmė kultūrinių, sporto objektų statybą. Pramonės plètra lėmė gyventojų skaičiaus išaugimą. $1991 \mathrm{~m}$. Marijampolèje gyveno apie 52 tūkst. gyventoju (Lietuvos socialinè raida... 1991: 11).

Lietuvai atgavus nepriklausomybę, Marijampolejje esančioms pramonès imonėms kilo sunkumų. Nuo 1992 m. pradejjo stipriai ir negrižžtamai mažèti pramonės įmonių gamybinès apimtys. $1995 \mathrm{~m}$. svarbiausios produkcijos gamyba buvo susitraukusi vidutiniškai tris, kai kurios dešimtimis kartų (Lietuvos apskritys... 1996: 262). Pramonès įmonių privatizavimas, restruktūrizavimas, produkcijos realizavimo problemos lėmė gamyklų uždarymą, susmulkẻjimą, darbą ne visu pajėgumu ar finansini sunkmeti (žr. Subačius 2009). Proporcingai didejjo bedarbių skaičius, kuris pirmą kartą Marijampolëje užfiksuotas 1991 m. - 57 bedarbiai (Lietuvos socialine raida... 1991: 21), 1993 m. - 1299, 1999 m. - 5062 (Lietuvos apskritys... 1999: 66). Vis dèlto Kęstutis Subačius atkreipia dėmesį, jog pramonei išgyvenant sunkmeti, mieste steigèsi smulkioji prekyba (Subačius 2009). Jau 1992 m. miesto laikraštyje minima, kad Marijampoleje yra 33 kioskai (Čeikauskienė 1992: 1). Marijampoleje, išskirtinai Lietuvos kontekste, nuo $1994 \mathrm{~m}$. sparčiai daugejjo automobilių: 1994 m. - 277 automobiliai 1000 gyventojų, 1998 m. - 544, o Vilniuje 1994 m. - 210, 1998 m. - 244 (Lietuvos apskritys... 1999: 286-287). Statistikos duomenys atspindi automobilių prekybos plètrą. Šiuo metu daugumą veikiančiu įmonių sudaro prekyvietės, įstaigos, teikiančios automobilių remonto, transporto ir saugojimo paslaugas (Marijampolès miesto šventę... 2016). Lietuvai atgavus nepriklausomybę, pramonės įmonės išgyveno pokyčius, o paslaugų teikimas ir prekyba tapo viena pagrindinių darboviečių. 


\section{Kauno gatvès vaizdinis pasakojimas}

Pokalbių metu pateikèjai ne kartą minëjo vieną pagrindinių ir ilgiausių Marijampolès gatviu - Kauno gatvę, čia esančias parduotuves, kioskelius, automobilių pardavimo vietas. Pasakojimuose įvardijama Kauno gatvė nusidriekusi nuo miesto centro iki pramoninio rajono, čia esantys objektai parodo įvykusius miesto vietu pokyčius. Norėdama pamatyti pateikèjų minimas vietas, vieną $2019 \mathrm{~m}$. gegužès diena, atvažiavusi i Marijampolès autobusų stoti, iš karto pajudejjau Kauno gatvès link. Ėjau siaura, vienpusio eismo gatve, kurios pabaigoje - „Lidl“ prekybos centras ir šalia esanti visiškai užstatyta automobilių stovejimo aikštelè. Toliau einant Kauno gatvės link, vos už gatvės linkio išniro du dideli naujos statybos prekybos centrai: „Maxima XXX“ ir "Norfa XL“. Ant jų fasadų - ivairiu, Lietuvoje žinomų parduotuvių ir paslaugu teikejju pavadinimai: "Jysk", „Danija“, ,Telia“, ,Can can“, ,Čili pica“, ,Drogas", ,Euro vaistinè", ,Benu”, , ,Betsafe”, „Elektromarkt", „Apranga“, „Deichmann“, „Sportland“. Parduotuves supa užstatytos automobilių stovėjimo aikštelès, o žmonės nuolatos įeina ir išeina.

Tik už vieno daugiabučio didelius prekybos centrus pakeitė parduotuvès ar paslaugas teikiančios įstaigos, įsikūrusios mažuose pastatuose. Vienos įmonès įsisteigusios ryškiaspalviuose mediniuose nuosavuose namuose, ant kurių kabo užrašai: „Naudota buitinè technika iš Vokietijos“, "Maisto prekès", „Baldai“. Ant balto namo „Baldai“ durų yra lapas su ranka užrašytu tekstu: „Išpardavimas. Rūbai $1 €^{\prime \prime}$. Kitos parduotuvès ar paslaugų teikèjai izsikūrę pavieniuose mediniuose, metaliniuose kioskeliuose, iš kuriu veikia keli: „Ne tik buitinė technika", "Mèsos gaminiai“ ir "Gèlès“, o netoliese esančiu metalinių aprūdijusių kioskeliu „Avalynès taisykla", "Gamina raktus, taiso spynas“ prekystaliai aklinai uždaryti, ant jų kabo nublukę lapeliai: „Parduodamas kioskas“. Mažų prekybinių pastatų languose ar ant vieno medinio namo taip pat kabo užrašas „Išnuomojamos patalpos“. Veikiančiu parduotuvių durys atidarytos, o prekès dviračiai, žoliapjovès, buitinė technika - išdèliotos priešais įejimus. Nepamačiau nė vieno žmogaus, užeinančio ị šias parduotuves ar išeinančio.

Einant toliau, Kauno gatvès panoramoje išniro daugiaaukščiai stačiakampiai Keramzitinio betono gamyklos pastatai. Gamybinis korpusas su produktų transportavimo linija apleistas: aptrupėję dažai, aprūdijusios metalinės detalès, išdužę langai, o administracinis pastatas sutvarkytas: perdažytas šviesiomis rudomis spalvomis, pakeisti langai. Buvusios gamyklos išore atskleidžia įvykusią pramonès įmonių fragmentaciją: dalis i̇monės toliau veikia, dalis uždaroma ar isteigiamos naujos. Prieš buvusią gamyklą Kauno gatvèje yra "Circle K" degalinè ir aptverta nedidelio ploto automobilių pardavimo aikštelè, prie kurios stoviniuoja du nelietuviškai kalbantys vyrai. Vos pusè aikštelès užimta, ant jos tvoros kabo reklama, skelbianti apie automobilių pardavimą ir gabenimą. 
Kauno gatvès tolumoje pamačiau apleistą išdužusiais langais, aptrupejjusiais dažais pramonini pastatą - Kauno statybos tresto gamybinę bazę, o kitoje gatvės pusėje - didesnę ir beveik visą užstatytą automobilių pardavimo aikštelę. Aptverta teritorija apima automobilių stovejjimo vietą ir pastatą ant kurio fasado - įmonès „T\&S mobile. Prekyba automobiliais”, jame esančiu draudimo imoniu pavadinimai. Priešais pastatą - reklaminis stendas su tos pačios įmonès pavadinimu ir išvardintomis teikiamomis paslaugomis: automobiliu pardavimas, saugojimas, variklių diagnostika. Kitoje aikštelès pusëje - lietuvių, anglų ir rusų kalbomis ženklas, nurodantis automobilių aukciono, priklausančio tai pačiai įmonei, vietą. Aplink aikštelę abiejose kelio pusėse išsidèstę pavieniai, veikiantys, kai kurie nublukę kioskeliai, lietuvių, lenkų ir rusų kalbomis siūlantys draudimo ar valiutos keitimo paslaugas. Gèliu gatvèje, besiribojančioje su aprašoma aikštele, išsidėstę naujai pastatyti ar atnaujinti pastatai, kuriuose įsikūrusios įmonès taip pat teikia automobilių remonto paslaugas, užsiima automobilių prekyba arba siūlo i̇vairias paslaugas: automobilių aukcioną, nuomą autoservisa, plovimą. Kauno gatvès pabaigoje ir besikertančioje gatvèje esančias įmones sieja su automobiliais susijusi veikla.

Eidama Kauno gatve pamačiau apleistas buvusias pramonès i̇mones, išnuomojamus menkus statinius, mažas parduotuves, automobilių prekybą ir su automobiliais susijusių įvairių paslaugų teikimą. Tačiau vaikščiojant matomi ne tik pavieniai vaizdai, bet sekamas miesto "tekstas" - pasakojimas, perteikiamas per esančius objektus (de Certeau 1988), sudarytas iš nutrūkstančių ženklų ir ispaudu serijos (Ingold, Vergunst 2016: 8). Kitaip tariant, Kauno gatvejje esantys pastatai ir kiti objektai susijungia i pasakojima, atskleidžiantị îvykusį industrinio vienodumo sutrupèjima, atsiradusią darbinès veiklos ir darbo vietų ịvairovę bei ekonominès veiklos plètrą. Šiandieninis gatvės vaizdas, pasakojantis, kaip buvo pragyventa deindustrializacijos sukelta darbo krizè Marijampolëje, yra žmonių veiksmų ir priimtų sprendimų pasekmè. Taigi kokie veiksmai ir sprendimai lèmė darbinès veiklos i̇vairovès atsiradimą ir formavimąsi Marijampolëje?

\section{Savarankiškai plètojamos darbinès veiklos pradžia}

Kioskai, mažos parduotuvės ar automobilių pardavimo aikštelès, įsiterpusios tarp didelių prekybos centrų ir apleistų sovietinių gamyklų, atskleidžia ịvykusius ekonomikos pokyčius Marijampoleje ir visoje Lietuvoje. Posovietinès patirtys kituose Lietuvos miestuose pristatomos per išgyvenimus uždarant industrines įmones, išryškinant, jog kartu su gamykla sugriūna ir darbininku gyvenimai (Šliavaitė 2010; Jurčikonytė 2016). Deindustrializacija Marijampolëje taip pat sukèlè nesauguma, tačiau tyrimo metu išryškèja įvairūs aktyviai plètojami veiksmai, kuriais siekta įveikti darbo krizę. Visą gyvenimą kultūros srityje dirbanti bei kurị laiką nereguliariai prekiavusi Elena aiškino, jog buvo ieškoma įvairių išeičių: 
Jauna mūsų šeima, vaikai maži ir toks darbas, darbo nėra, atlyginimų nemoka. Parsiveždavai iš Klaipedos ar iš Panevėžio sūreliu, čia Marijampolèje parduodi, nu va šitaip. Arba pašaru vištom, čia iš savo šeimos patirties. $\mathrm{Nu}$ sukdavaisi, reikia prisidurt. Ir ieškai, kur dar sugebi kažką daryt (Elena ${ }^{3}, 56$ m.).

Taigi buvo pasinaudojama atsiradusiomis galimybèmis gauti pajamų ar jas padidinti: „Marijampolëje jie čia vis tiek, tuoj čia, kaip sakysim, atsidarè sienos $^{4}$ - tai aišku čia visi èmè važinèt ir prekiaut" (Benediktas, 63 m.). Dažniausi pragyvenimo būdai buvo prekyba ir paslaugu, tokių kaip automobilių ar buitinès technikos remontas, teikimas. Ivairią prekybą praktikavo gamyklų darbininkai ir darbuotojai, mokytojai, kultūros darbuotojai. Ja užsiimta tikslingai - prekyba tapo pagrindine veikla, teikiančia pajamas, arba protarpiais - pasinaudojama galimybėmis padidinti pajamas. Pirmiausia iš Lietuvos „vežè viską“: pieštukus, kamuolius, žirkles, cigaretes, sukneles, kepures, mezginius, dešras į Lenkijos turgus. Vèliau èmė prekiauti prekèmis, atvežtomis iš užsienio, bei maisto produktais Marijampolès gatvėse, kioskuose, turguose. Didžiąją dali Marijampolejje plètotos prekybos sudarè prekyba automobiliais ar vadinamasis „mašininiu“" verslas.

Kioskų atsiradimas ir „mašininių" verslo pradžia Marijampoleje sietina su individualia ar šeimos ekonomine padètimi, darbovietės (ne)stabilumu ar siekiu padidinti pajamas. Galima išskirti kelis veikimo modelius, kaip žmonės pradèjo savarankiškai plètoti darbinę veiklą. Pirmasis - imamasi individualios veiklos remiantis profesija ar turima darbine patirtimi. Pavyzdžiui, Juozas $(57 \mathrm{~m}$.), šiuo metu dirbantis mažoje pramonès įmonèje, sovietmečiu dirbo autoremonto gamykloje $^{5}$ ir, kaip pats sako, „šiek tiek" teikè butu remonto paslaugas, pats nesièmè individualios veiklos, tačiau pajutęs, kad vyksta pokyčiai, perëjo dirbti i statybos kooperatyvą kuri buvo įsteigęs vienas iš "Pramprojekto" inžinierių. Juozas sakè, jog visi ieškojo geriau apmokamos darbo vietos arba pradejo dirbti savarankiškai, pavyzdžiui, ne vienas jo bendradarbis mechanikas ėmėsi individualiai remontuoti automobilius. Šiuo atveju siekiant pragyventi, buvo tęsiama ta pati veikla pasikeitus darbiniams santykiams.

Antrasis - neformalios darbinès veiklos, pradètos sovietmečio pabaigoje, tęsimas. Siekiant palengvinti prekių i̇sigijimą ir paslaugų gavimą socialistinèje trūkumo ekonomikoje, susiformavo ",antroji ekonomika“, apėmusi nelegalią namudinę gamybą ir privačią prekybą, naudojimąsi gamyklų ištekliais, kontrabanda, paslaugų teikimą (Sampson 1987; Verdery 1996). Parazitinių santykių su oficialia ekonomika pagrindu funkcionavusi „antroji ekonomika“ buvo individualus problemų sprendimo būdas ir integrali kasdienio gyvenimo dalis,

\footnotetext{
${ }^{3}$ Straipsnyje pateikejų vardai pakeisti.

${ }^{4} 1993$ m. įsigaliojo bevizis režimas su Lenkija (Lietuvos Respublikos Vyriausybès... 1993).

${ }^{5}$ Autoremonto gamykloje visapusiškai taisyti GAZ sunkvežimiai.
} 
tenkinusi daugumą poreikių (Verdery 1996; Hohnen 2007). Nors verslumo legalizavimo ir plètros užuomazgu galima matyti vèlyvuoju sovietmečiu (žr. Tranavičiūtė 2012), tačiau dar ir po Lietuvos nepriklausomybės atgavimo sovietmečiu pradètos nelegalios veiklos išliko neformaliu papildomu pajamų šaltiniu ar pragyvenimo būdu. Pateikèjai, pasakodami apie pragyvenimo būdus Marijampolëje, pabrèžia, jog „baigèsi Jugoslavijos, ir tas pradejjo važinèt i̇ Vokietiją“. Kitaip tariant, važiavimas i kitas šalis prekiauti buvo viena iš galimybiu pragyventi ar papildomai užsidirbti. Petras (63 m.), šiuo metu dirbantis vadybininku pramonės i̇monèje, yra vienas žmonių, kuris važinėjo ir prekiavo vėlyvuoju sovietmečiu ir Lietuvai atgavus nepriklausomybę. Vienam bendradarbiui pasiūlius, pradejjo „varinèti“ iš Vokietijos ir pardavinèti automobilius Marijampolëje. Šią veiklą vykdè 1993-1999 m. Prieš automobilių „varinèjimą“ Petras kartu su žmona važinėdavo i̇ Jugoslaviją ir pardavinėdavo savo megztus megztinius, kepurèles, grąžtus, atsuktuvus, dešras. Petro teigimu, Jugoslavijoje „viską ką tu pajègi nusivežti, tą gali parduoti“. Apie galimybę prekiauti Jugoslavijoje taip pat sužinojo iš bendradarbio. Nors tuo metu turëjo "gerą darbą" - dirbo vienos gamyklos cecho direktoriaus pavaduotoju, tačiau pradèjo prekiauti, nes „čia pinigai, neina ju palikt“. Nors važinejjimo kryptys ir prekiaujamos bei gaminamos prekès (pavyzdžiui, mezginius pakeitè žaislų siuvimas) nuolatos kito, o sužinoti apie naują Petro žodžiais tariant, "skylę" reikejjo asmeninių kontaktų, tačiau paties veiksmo - važiavimo ir prekiavimo - tęstinumas išliko. Verta atkreipti dèmesi, jog daugelis „mašininių“, kaip ir Petras, prekiauti automobiliais baigè po 1998 m. Rusijos ekonominès krizès, kuri paveikè ir „mašininių“ verslą. Važinejjama ir prekiaujama buvo tol, kol verslas funkcionavo sklandžiai: nereikejjo investiciju ar koreguoti prekybos modelio.

Aptarti atvejai atskleidžia dar vieną aspektą - asmenines pažintis ieškant pragyvenimo būdų, norint pagerinti individualią ar šeimos ekonominę padètị. Asmeninès pažintys - giminès, draugai ir kolegos - posovietiniuose antropologiniuose tyrimuose atskleidžiamos kaip būdas, kuris pasitelkiamas siekiant privatizuoti imones ar kontroliuoti prekių įsigijima, gauti finansavimą individualiam darbui, apsisaugoti ar išgyventi (Verdery 1996; Humphrey 2002; Heyat 2002; Nielsen 2006). Turimų pažinčių aktyvavimas dažnai suvokiamas kaip vienas pagrindinių būdų išgyventi nesaugumą. Lauko tyrimo metu Marijampolès mieste asmeninės pažintys išryškèjo kaip „savęs įdarbinimo“ pradžia.

Marijampolëje individualios darbinès veiklos formavimosi pradžioje asmeninès pažintys padèjo îsitraukti i tam tikrą veiklą. Vis dèlto artimi kontaktai dažnu atveju pasitelkti ne pačių kioskelių savininkų ar „mašininių“ iniciatyva. Iš pateikejju pasakojimų aiškejja, jog daugelis individualiai dirbti pradèjo paskatinti draugu , kolegu ar giminių. Kitaip tariant, jiems kažkas „pasiūlè , „išsivežè", „prikalbino“, „pasièmé", „pasišnekino“. Tam tikrais atvejais pati veikla ir 
verslumas skatino plèstis ir įtraukti artimus asmenis. Tai atskleidžia Kazimiero, sovietmečiu dirbusio treneriu, vèliau netekusio darbo ir atidariusio kioskeli bei „varinejjusio“ automobilius, dabar dirbančio mokytoju, pasakojimas:

Išejau i savo nuosavą verslą. Pradëjom prekiaut. Pradžioj ten giminaitis augino gèles, tai kažkaip taip pakalbino, galima gèles ten, žodžiu, jie ten žydino. <...> i Vilnių veždavo, tai jiems ten sekdavosi tas biznis. Nu ir norejo, kad daugiau kažkas dar prekiautu, nu tai mus prikalbino. Bandèm mes su tom gèlėm, bet auginom tiktai lauke. Tai anksti pavasarị, kada pražysta narcizai, veždavom ten i turgelị, tai Motinos diena būna, tai dar kažkokios pavasarinès, kurios anksti pražista. Tai kažkiek parduodavom, bet tas biznis būdavo labai menkas. <...> Bet, žodžiu, sunki ta pradžia buvo, kažkiek ten, kažkiek pinigèliụ užsidirbdavom. Bet tada dar dirbdavau ir sporto mokykloj, bet kai uždaré tinklinį, o ta mūsų prekybẻlè lyg tai tokia vystèsi, pasistatėm kioska, vieną iš pirmujjų Marijampolëje. <...> nu ir prekiavom daržovèm, vaisiais ir smulkiomis ten maisto prekèm. <...> To biznio ir ne kažkas likdavo. Bet kada mažai būdavo tos prekybos tinklų, turgelis arba kioskeliai, tai kažkokia apyvarta būdavo. Paskui truputi plètėmės, tai saldumynai kažkoki, arbatos, kavos ar dar kažkas tai. $<\ldots>$ Šalia to aš gi dar važiavau i Vokietija, nes iš Marijampolès ten kas antras važiuodavo prekiauti automobiliais. Aš tik turëjau [ỉsigijau] teises ir mane išsivežè ị Vokietiją. Mane pasièmè, nes aš vokiečiu kalbą mokèjau. O jie tiktai rusų mokèjo, angliškai irgi ten nesusikalbėsi. <...> Tai važiavom jiems padèt susikalbèt, bet po truputi aš isitraukiau ir su tais automobiliais, manau, kokius penkis metus irgi. Po truputi, ne dažnai, ne stipriai, bet važiuodavom ir grižzavom, nuvažiuodavom ir griždavom (Kazimieras, 59 m.).

Kazimiero pasakojime išryškëja, kad i veiklų tinklą galima įsitraukti, bet dalyvauti nereguliariai ir tik kuri laiką. Kita vertus, veiklą galima plètoti aktyviai ir ją plèsti. „Savęs i̇darbinimą" ne visi inicijavo vienodai. Vieni pasinaudojo atsiradusiomis galimybėmis ir ísitraukè aktyviai arba palaikė veiklą, kiti patys inicijavo „savęs įdarbinimą" tęsdami oficialią ar nelegalią darbinę veiklą plètotą sovietmečiu.

\section{„Savęs įdarbinimas" ir naujų darbo vietų kūrimas}

„Vaikeli, kas per pramonė buvo“ (Mykolas, 73 m.). Taip sakydamas pensininkas Mykolas, buvęs automatu gamyklos ${ }^{6}$ darbininkas, apibūdino ne sovietmečiu pastatytas gamyklas ir kombinatus, bet verslumu pagristus ekonominius procesus, vykusius Marijampolëje Lietuvai atgavus nepriklausomybę. Mykolo pastebèjimas ir Kauno gatvëje prie automobilių pardavimo aikštelès išdėstyti pastatai, kuriuos sieja veikla, susijusi su automobiliais, atskleidžia, jog prekyba automobiliais sudare sąlygas kurtis kitoms, šalia prisiglaudusioms ekono-

${ }^{6}$ Šitaip vadinamas Kapsuko TSRS 50-mečio maisto pramonès automatu gamybinis susivienijimas. 
minėms veikloms: privačioms automobilių saugojimo aikštelėms, turgui, automobilių remonto, apgyvendinimo paslaugas teikiančioms įmonėms, pardavimų tarpininkams. Kaja Kaźmierska pažymi, kad kolektyvinis įsitraukimas ì prekybą gali būti įvardintas kaip „,bendras verslas“ (Kaźmierska 2006: 70). „Bendras verslas" apima ir mokytojo Jono, kuris visada turèjo nuolatini darbą, tačiau, siekdamas gauti papildomų pajamų, prisidejo prie „mašininių“ ir isteigè kioskeli, pasakojime išryškejjusi naujų darbo vietų kūrimą:

Pradejo važinèti i Vokietija, varyti automobilius, kas patys pirmieji, visi susipirko tuos vadinamus tralus labai greitai, nes buvo dideli pinigai, dideli uždarbiai, nes dar ne daug kas važiavo. Aš irgi kaip visada pavèluodavau, nes darbas mano, tai etapas mano buvo i̇ Vokietiją važiuoti per atostogas vasaros. Tai irgi išsivežè, tai pirmą kartą aš važiavau, tai nieko tu nežinai, ką pirkt, kaip pirkt, ten kas jau atkutę, matėm ten, tas žinojo <...>, o mes ten bet ką nusipirkom po mašina, gryno pelno 200 dolerių liko. <...> Ir taip paskiau, neatsimenu, kiek ten tų metų irgi per atostogas vis važinėdavau i Vokietiją. Būdavo, kad tikrai geri uždarbiai, tikrai geri. Irgi kaip sakau, tas padejjo ta finansine prasme. <..> Ir paskiau aš i tą Vokietiją pradejjau važinèt, žmona be darbo [dirbo automatu gamykloje, buvo atleista] - ką daryt. Čia to darbo toj Marijampolèj, tos i̇monès, fabrikai pradèjo užsidarinèti, neypatingai to buvo. Tai sugalvojom, nes tie turgūs buvo Marijampolejje automobilių, čia visoj Lietuvoj, iš Maskvos atvažiuodavo, tampa žinoma ta Marijampole <...>. Tai išmąsčiau, <...> kad reikia aptarnavimo srity toki vadinamą kioską [turguje]. Vieną iš pradžių pastatėm, pastačiau ir žmona pradejo dirbt tam kioske, teikt maitinimo paslaugas. Maitinimo paslaugas: kava, arbata, karbonadas, cepelinai, čeburekai. Iš pradžių pradèjo kažką daryt pati, bet būdavo irgi tokia niša, niša maitinimo paslaugų, žmonių srautas didelis, tai visi valgè ten ir maisto matèsi didelis trūkumas buvo. Aišku, ir konkurencija greit atsirado, ir kiti žmonès pradejjo kioskelius statytis vienaip ar kitaip. Tai jinai paskui jau pati irgi ieškodavosi kas daro pusfabrikačius, jau pirkdavo, jau pati irgi nedirbdavo. <...> nu bandè pradèt gamint, pradžia nuo kažko tai turi būt, kad tu ieitum ị tą versliuką menką tokį, kad pati ir karbonadus pati kepè, ir cepelinus pati bandè daryt, bet nu visko nespejjo padaryt kiek reikia. Tai paskui susirado, kas cepelinus daro, po kiek laiko susirado, kas čeburekus kepa, tai vèl ką. Tai tokį ratą. < ..> Paskiau pradèjo pati, matè, šakės, nespèja viena, pasisamdè draugę. Tai jau dviese, kaip ir neblogai, ir atsidaro kitas turgus paskui Marijampolëje. Tai vieną tą kioskeli turëjom vienam turguj, kitą kitam. <..> Ir taip paskiau dirbo žmona tuose turguose, tuose savo kioskuose. Ir jai irgi gerai gaudavosi. Aišku, reikèdavo, va darbas nuo penkių ryto ar nuo šešių tenai, ji keldavosi, važiuodavo, viską ir dirbdavo, ir samdèsi darbuotoją. Buvom įmonę i̇sikūrę, įsikūrę individualią i̇monę. <...> Ten kažkokius mokesčius reikèjo mokèt, jau net neatsimenu, senas laikas buvo. Ir paskui aš mačiau, aišku, aš nespèju i tą Vokietiją važinèt, darbas mano, tai atsidariau aš aaa... prie tos įmonès kitą veiklą, reiškiasi, formint pirkimo pardavimo sutartis automobilių. Tai aš po pamokų nuvažiuoju, kiek tenai pats padirbdavau. Ir prieš tai irgi samdydavau žmogų, mokėdavau jam sutartą atlyginima, a ne, sutartą atlyginimą ir jisai ten iš ryto mano pamokų laiku jis ten dirbdavo (Jonas, $59 \mathrm{~m}$.). 
Jono pasakojimas atskleidžia individualaus veikimo logika, kurios pagrindu kuriasi naujos darbo vietos ir ekonominès veiklos. „Savęs įdarbinimą“ ir prekiavimo pradžią lèmė asmeninis siekis pagerinti šeimos finansinę padètị. Vis dèlto tolesni sprendimą - izsteigti maitinimo paslaugas teikianti kioskeli - paskatino darbinè Jono kasdienybe ir iš jos kylantys poreikiai. Kuriant naują darbo vieta, atsižvelgta ne i̇ žmonos specialybę ar profesinius igūdžius, bet vadovautasi patirtimi, igyta dirbant automobiliu turguje. Atkreiptinas dėmesys, jog kioskelio teikiama paslauga susijusi su moterims tradiciškai priskiriamomis pareigomis ir darbais. Taip dalis tradicinės moteriškos kasdienybès tapo nauja darbo vieta, duodančia pajamų. Remiantis dviejų kasdienybių patirtimis - vyro darbo ir moters namų - buvo sukurta nauja individualaus darbo vieta.

Kaip galima matyti iš tolesnio Jono pasakojimo, naujos darbo vietos kurtos toliau vadovaujantis darbinės veiklos logika. Didejjant darbo apimtims ir atsirandant plètros galimybėms, samdomi kiti asmenys, ne šeimos nariai. Vadovaujantis patirtimis, kinta veikimo forma: individualius mašinu „varinëjimus" keičia tralai, kuriems vairuoti samdomi asmenys, ar autobusiukai nuvežti „mašininius" i automobilių turgus užsienyje. Jono atveju nebegalejjimas suderinti ilgų kelionių ir nuolatinio darbo mokykloje lėmè veiklos pokyčius. Nors jis priklausė „mašininių" verslui, tačiau teike paslaugas vietoje ir pasyviai - nejudejo tarp šalių. Vadovaudamasis verslo logika, vietoje savęs įdarbino kitą asmenį ir šitaip sukūrè naują darbo vietą. Taigi randasi struktūros užuomazga, kurioje yra darbo pasidalijimas: įdarbintas asmuo gauna fiksuotą atlyginimą, o verslą pradėjęs ikūrëjas tampa darbdaviu - asmeniu, teikiančiu įdarbinimo paslaugas. Vadovaujantis darbinès veiklos ir verslumo logika ne tik sukuriama nauja darbo vieta, bet keičiasi ir darbiniai santykiai.

Verslas, prasidėjęs nuo vieno žmogaus, ittraukia šeimos narius, draugus ir toliau gali plèstis bei pereiti iš neformalios veiklos į formalią. Monika, „mašininio“ žmona, sovietmečiu dirbusi automatu gamykloje, šiuo metu „oficialiai“ dirbanti vyro įmonèje, atskleidžia, kaip pamažu neformali individuali veikla formalizavosi: „turbūt pradžioj nelegaliai, paskui jau ten pradejjo mokesčių inspekcijos eit, ar tu ten dirbi, tai verslo liudijimas, o paskui, dabar jau daug metu tai UAB“ (Monika, 54 m.). Jono pasakojime taip pat išryškẻja, jog ",savęs įdarbinimas“ gali formalizuotis, kai darbinè veikla pradedama plètoti legaliai: mokami mokesčiai, įdarbinami kiti asmenys ir šie gauna atlyginimą. Kauno gatvejje esančios automobilių pardavimo ir remonto įmonès - tai "mašininių“ verslo ir šalia jo prisiglaudusių kitų ekonominių veiklų formalizavimo rezultatas ir šiandieninio gyvenimo dalis. Taigi atsiradusios darbinès struktūros nėra uždaros, jos turi tendenciją plèstis ir formalizuotis dèl iškylančiu poreikių.

Kita vertus, naujų darbo vietų steigimas gali neturèti tiesioginių tarpusavio ryšių, o būti susijęs su bendru vietos verslumu: 
Verslo šaka buvo, kuri vertėsi iš mašinų. Taip ir sakiau, Marijampolè - viskas. Nes ir kirpyklos, nu, nes viskas klestejjo iš to, nuo kada klestëjo mašinu verslas. $\mathrm{Nu}$, tai verslininkų žmonos, visi turëjo darbo. <...> Tie kurie... [aplink įsikūrę] čia verslininkas, čia verslininkas, sekantis namas verslininkas. Visi yra mašininiai. Už šito mašinas taiso ir dabar dar vis taiso. < ...> Tikrai, Marijampolè labai, labai su šituo susiję (Monika, 54 m.).

Monikos pasakojimas rodo, kad iniciatyvos steigti naujas darbo vietas pirmiausia kyla šeimoje ir su „bendru verslu“ gali būti susijęs šeiminiais ryšiais, o vienu esminių veiksnių, lemiančių ekonominès veiklos sukūrimą ar plètima, yra finansinès galimybès ir uždarbis. Apskritai „mašininių“ verslas sudarè sąlygas kurtis naujoms darbo vietoms, joms plèstis ir itraukti kitus asmenis.

\section{Darbo sampratos pokytis: darbas ar "savas verslas"}

Sovietmečiu stabilus apmokamas darbas buvo pateiktas kaip priešingybė individualiai veiklai ir verslumui. Verdery pažymi, kad samdomas darbas suvokiamas kaip saugus ir suteikiantis užtikrintą ateiti, priešingai, nei „savęs iddarbinimas" (Verdery 1996: 215). Hohnen, atlikusi tyrimą Gariūnuose 1995 m., pabrèžia, jog privati prekyba posovietmečiu sietina su socialistine spekuliacijos samprata - nelegaliais, neteisètais ar amoraliais veiksmais, dèl to suvokta kaip „ne darbas" ar „netikras darbas", asocijuojama su sejdejimu ar laikina veikla, kuriai nereikia specialaus pasirengimo (Hohnen 2001; Hohnen 2007). Vis dèlto, antropologès manymu, prekybos kaip moraliai ir socialiai problemiškos veiklos supratimas gali būti sietinas su tuo, kad „tokia veikla nebuvo (dar) ìvertinta kaip profesija“ (Hohnen 2007: 117).

Remiantis Hohnen izžvalga, būtų galima teigti, kad iki šiol prekyba yra moraliai, socialiai problemiška veikla, nes ir šiandien pateikèjai neapibrèžia jos kaip profesijos, kuriai reikalingi specialūs igūdžiai. Vis dèlto pateikèjai pažymèdavo, jog ne kiekvienas gali prekiauti: „mes neprekiavom. Ne prekeiviai“ (Marija, 58 m.). Paaiškindami, kodėl neprekiavo ar prekyba netapo pagrindiniu pragyvenimo šaltiniu, pabrèžia asmenines savybes. Būti prekeiviu reiškia „, turèti gyslelę" - būti gudriam ir mokèti pasinaudoti galimybèmis. Priešingai, nei aiškina Hohnen, šios savybès ir pati veikla nèra siejama su amoraliais veiksmais. Kadangi „savęs įdarbinimas“ suvokiamas kaip būdas, kuriuo galima susikurti asmeninę gerovę, apie prekiavimą ir verslumą pasakojama su tam tikra pagarba. Pagarbos elementas atsiranda „savęs įdarbinimą“ konceptualizuojant kaip ilgalaikę veiklą, ivertinant sunkumus ir pačią darbo raida, kai pradèjus nuo smulkios prekybos vẻliau i̇sigyjamos gamyklos, i̇steigiamos i̇monės, prekyvietės. Pensininkė Danutè, sovietmečiu dirbusi Marijampolès gamybiniame susivienijime, vèliau pakeitusi ne vieną darbovietę, nurodo pastangų svarbą: 
Buvo kaimynų mergaite, jau nu technikumą baigus, bet taip jau su darbu striuka, bet ji tiek jau norèjo gyvent. Tai ji raskladūškę nusipirkusi ir ant tos raskladūškès savo veiklą pradejjo turguj. Paskui ị Turkiją važinèt, užuolaidas vežt ir suklestejjo. <...> Jai ten kokia teta davè toki namioka, kad tom užuolaidom užsiimt. Grynai tèvų, tėtis <...> tą mergaitę nuveža su ta raskladūške i turgų, ji išsidèsto tas savo užuolaidas, o dabar kioskeli ji turi ir namą pasistačiusi iš užuolaidų. Ir dar dabar iš tos Turkijos veža tas užuolaidas (Danutè, 73 m.).

„Gyslelès turëjimas" apibūdina ne tik gerą prekybininka, bet ir verslininką. Pateikèjai žodžius „verslininkas“ ir "prekybininkas“ vartoja kaip sinonimus. Pensininkè Ana, visą gyvenimą dirbusi trenere, tačiau po nepriklausomybès atgavimo protarpiais neformaliai prekiavusi, taip pat nedaro skirties:

Jie gudručiai <...>, tuos kamuolius ir brangiai pardavè, gerai užsidirbo ir greitai, ir jie sau vaikšto po tą turgų. $\mathrm{O}$ aš, kai man pasakè, kad ten pieštukų, te vèl kokių šūduku prisipirkau, žinai, dar pinigu prisiskolinus, ir sèdžiu aš tam. O šita mergos ten, jau jos irgi tokių pačių prisipirkę ir sako: „Trenere, iš jūsų vagia." Žinai, atsisuku - jau ten kažkas tai neša man. Nu aš, aš nesu, nu visiškai esu tokia kaip pasakyti, nu tikrai ne verslininkè, neturiu jokios gyslelès. Ten mane gali apgaut ant, ant bileko. <..> Tai parsivežiau kažkiek tų kapeikų. Paskui jau gudrejji, jau gudrèji (Ana, 72 m.).

Hohnen teigimu, verslas, kitaip nei prekyba turguje, suvokiamas labiau kaip darbas nei nedarbas (Hohnen 2001: 75). Pateikejjams sugretinant verslą ir prekyba, išryškèja įvykęs darbo sampratos pokytis.

Pateikëju pasakojimuose vartojama „verslo“ sąvoka yra platesnè nei prekyba per se. Viena vertus, verslas suvokiamas kaip „savęs i̇darbinimas“. Šiuo atveju sąvoka apima ne tik prekybą ar paslaugų teikimą kaip veiksmą, bet ir nurodo nuosavybę - „turèti savo“ i̇monę, parduotuvę, kioską ar gamyklą. Pabrèžtina, jog pateikejjai neakcentuoja skirtumo tarp žmogaus, kuris yra įsigijęs ar įkūręs gamyklą, ir, pavyzdžiui, automobilių prekeivio. Šiuos asmenis, turinčius konkretų objektą kaip savo nuosavybę ir užsiimančius tam tikra individualia veikla, sieja „savo verslo" plètojimas: „Jis dirbo Pieno konservų kombinate, valdiškame darbe, o paskui pradejjo savo verslą... nu ir vien tuo pasijuto labai, kad galejai savo turèt" (Monika, 54 m.). Pateikèjai nedaro skirties tarp „verslo“ ir "savo verslo". "Savo verslas" siejamas su aktyvumu, iniciatyvumu: "tikrai visi žinojo tą versliuka, kas netingėjo, nesėdèjo, tas galejo važiuot" (Petras, 63 m.). Kita vertus, jau Petro žodusiuose išryškèja, jog verslas gali nurodyti bendrą veiklos sriti, pavyzdžiui, „mašininių“" ar "garažinių" verslas. Šia prasme „verslas" suvokiamas kaip ivairios veiklos, vienaip ar kitaip susijusios su tam tikru objektu ar vieta. „Mašininių“ verslas apima automobilių „parvarymą", pardavima, kitas teikiamas paslaugas: draudimą, sutarčių sutvarkymą, apgyvendinimą. $\mathrm{O}$ "garažinių" verslas - tai darbai, įsikūrę garažuose, dažniausiai įvairios remonto dirbtuvès. 
Konceptualizuojant „savęs įdarbinimą“ kaip verslą prekyba ir įvairių paslaugų teikimas igyja tapatumą bei socialini pripažinimą. "Savęs įdarbinimas" nebuvo tik pragyvenimo būdas ar individuali darbinè veikla, jis suvokiamas plačiau: kaip „savas verslas“, individualus aktyvumas, iniciatyvus savarankiškas darbo vietos susikūrimas, užsièmimas darbine veikla ir nuosavybės turejjimas. Žmonès, plètojantys „savo verslą“, įvardijami kaip verslininkai - asmenys, pasižymintys veiklumu ir gudrumu bei galintys igyti tam tikrą vardą: ",mašininis“, "garažinis".

\section{Išvados}

Siekiant pragyventi deindustrializacijos primestus iššūkius, pasitelkti darbiniai ir verslumo igūdžiai, igyti sovietmečiu; pasinaudota atsiradusiomis galimybėmis: asmeninėmis pažintimis ar vietos verslumu; aktyviai arba nereguliariai užsiimta individualia darbine veikla. Tačiau pragyvenimo būdai buvo ne tik laikinas „savęs įdarbinimas“, kai individualiai susikurtoje darbo vietoje asmeniškai plètojama darbinè veikla, ar siekis išgyventi darbo krizę, bet praktikos, sukūrusios naują socialinę ir ekonominę struktūrą Marijampoleje. Veiklų ìvairovè ir gausa, susijusi su automobilių „varinèjimu“ ir prekyba, lėmė „mašininių“ verslo atsiradimą. Vadovaujantis darbinès veiklos logika susiformavo „savęs įdarbinimo“ principu grįstas „bendras verslas“, apėmęs automobilių „varinèjimą“, įvairių paslaugų teikimą ir prekybą. İsitraukimas į bendrą "mašininių" verslą sudarè sąlygas prisitaikyti prie kapitalistinès sistemos vertybių ir idejjų bei tokiu būdu pragyventi posovietinę deindustrializaciją.

Kauno gatvejje esančios įvairios apimties ir pobūdžio įmonès atskleidžia, kad „savęs įdarbinimas" yra šiandieninio miesto dalis ir ilgalaikis reiškinys, iš neformalaus pragyvenimo būdo - pastangu pragyventi nestabilius laikus tampantis formalia darbine veikla. Darbinės veiklos plètojimo ilgalaikiškumas, pastovumas ir įsitvirtinimas mieste lėmė darbo sampratos pokytị. Tiek neformalus, tiek formalus „savęs įdarbinimas“ kartu su nuosavybès - „savo“ - turëjimu konceptualizuojamas kaip „verslas“. Pabrěžtina, jog verslo polinkis plèstis - įtraukti šeimos narius ir draugus - sudare sąlygas kurti naujas darbo vietas ir formuoti naujas struktūras, paremtas darbo pasidalijimu. Kitaip tariant, pačios veiklos ir ju sudarytas tinklas skatino pradèti, plèsti ir formalizuoti „savo verslą", kuris siejamas su aktyviu ir iniciatyviu asmeninės gerovès kūrimu. Darbo krizè, atsiradusi posovietinès deindustrializacijos metu, buvo pergyventa pasinaudojant „verslo“ polinkiu augti. Verslumas, galèjęs būti sovietmečio pabaigoje igytų igūdžiu plètojimu ar po Lietuvos nepriklausomybès atgavimo naujai formuojama praktika, padëjo įveikti deindustrializacijos iššūkius.

Kauno gatvejje tarp dideliu prekybos centrų ir apleistų sovietinių gamyklų išsidėsčiusios automobilių aikštelès, parduotuvėlès, i̇monès, teikiančios automobilių remonto, plovimo, nuomos, pardavimo paslaugas, ir šalia esantys kioskai - 
tai darbinès veiklos įvairovè, išardžiusi ir susmulkinusi industrini vienodumą. Būtent individualus aktyvumas ir pragyvenimo kūrybingumas, lèmęs îvairiu ekonominių veiklų atsiradima, suardè industrinį vienodumą. Posovietinės deindustrializacijos sukelta darbo krizè Marijampolès mieste buvo pergyventa kuriant kitokias, negu pramonės įmonèms būdingos, darbo vietas.

\section{Literatūra}

Ashwin, Sarah. 1999. Redefining the Collective: Russian Mineworkers in Transition, M. Burawoy, K. Verdery (eds). Uncertain Transition: Ethnographies of Change in the Postsocialist World: 245-272. Lanham, Oxford: Rowman \& Littlefield Publishers.

Barthes, Roland. 1982. Empire of Signs. New York: Hill and Wang.

Buchowski, Michal. 2004. Redefining Work in a Local Community in Poland: "Transformation" and Class, Culture, and Work, A. Procoli (ed.). Workers and Narratives of Survival in Europe: The Management of Precariousness at the End of the Twentieth Century. SUNY Series in the Anthropology of Work: 173-196. Albany: State University of New York Press.

Burawoy, Michael; Verdery, Katherine. 1999. Introduction, M. Burawoy, K. Verdery (eds). Uncertain Transition: Ethnographies of Change in the Postsocialist World: 1-18. Lanham, Oxford: Rowman \& Littlefield Publishers.

Cowie, Jefferson; Heathcott, Joseph. 2003. Introduction: The Meanings of Deindustrialization, J. Cowie, J. Heathcott (eds). Beyond the Ruins: The Meanings of Deindustrialization: 1-15. Ithaca: ILR Press.

Čeikauskienè, Aldona. 1992. Kioskas - vietoj vejos?, Suvalkietis 0808 (122(7092)): 1.

De Certeau, Michael. 1988. The Practice of Everyday Life. Berkeley, Los Angeles, London: University of California Press.

Drėmaitè, Marija. 2016. Progreso meteoras: modernizacija ir pramonés architektūra Lietuvoje 1918-1940 m. Vilnius: Lapas.

Dunn, Elizabeth C. 2004. Privatizing Poland: Baby Food, Big Business, and the Remaking of Labor. Culture and Society after Socialism. Ithaca, London: Cornell University Press.

Edensor, Tim. 2010. Walking in Rhythms: Place, Regulation, Style and the Flow of Experience, Visual Studies 25(1): 69-79.

Harvey, David. 1990. The Condition of Postmodernity: An Enquiry into the Origins of Cultural Change. Cambridge, MA, Oxford: Blackwell Publishers.

Harvey, Penny; Krohn-Hansen, Christian. 2018. Introduction. Dislocating Labour: Anthropological Reconfigurations, Journal of the Royal Anthropological Institute 24(S1): 10-28. 
Heyat, Farideh. 2002. Women and the Culture of Entrepreneurship in Soviet and Post-Soviet Azerbaijan, R. Mandel, C. Humphrey (eds). Markets and Moralities: Ethnographies of Postsocialism: 19-31. Oxford, New York: Berg.

Hohnen, Pernille. 2001. Gariūnų marginalizacija: turgaus kultūrinė antropologija, Lietuvos etnologija: socialinés antropologijos ir etnologijos studijos 1(10): 63-83.

Hohnen, Pernille. 2007. A Market out of Place? Remaking Economic, Social, and Symbolic Boundaries in Post-Communist Lithuania. Oxford Studies in Social and Cultural Anthropology. Oxford: Oxford University Press.

Humphrey, Caroline. 1995. Introduction, The Cambridge Journal of Anthropo$\log y$ 18(2): 1-12.

Humphrey, Caroline. 2002. The Unmaking of Soviet Life: Everyday Economies after Socialism. Ithaca, London: Cornell University Press.

Ingold, Tim; Vergunst, Jo Lee. 2016. Introduction, T. Ingold, J. L. Vergunst (eds). Ways of Walking: Ethnography and Practice on Foot. Anthropological Studies of Creativity and Perception: 1-19. Abingdon, New York: Routledge.

Jaffe, Rivke; de Koning, Anouk. 2016. Introducing Urban Anthropology. Abingdon, New York: Routledge.

Jurčikonytė, Aušra. 2016. Sovietinè industrija ir poindustrinės atmintys: Alytaus namu statybos kombinatas, Lietuvos etnologija: socialinés antropologijos ir etnologijos studijos 16(25): 155-175.

Jurčikonytè, Aušra. 2017. Alytaus miesto urbanistine raida modernizacijos procesuose 1964-1996 m. Magistro darbas. Vilnius, Vilniaus universitetas, Istorijos fakultetas.

Kaźmierska, Kaja. 2006. The Border as an Individual and Collective Experience - The Sejny Case, J. Kurczewska (ed.). Polish Borders and Borderlands in the Making: From the Field Studies of Polish Sociologists and Anthropologists: 63-87. Warsaw: IFiS Publishers.

Kesküla, Eeva. 2018. Labor, Employment, and Work, H. Callan (ed.). The International Encyclopedia of Anthropology. <https:/onlinelibrary.wiley.com/doi/ book/10.1002/9781118924396> [žiūrèta 202004 04].

Kideckel, David. 2001. Labor and Society in the Jiu Valley and Fagaras Regions of Romania I: Variations in Response to the Crisis. Washington: The National Council for Eurasian and East European Research.

Kjaerulff, Jens. 2015. Introduction, J. Kjaerulff (ed.). Flexible Capitalism: Exchange and Ambiguity at Work. EASA Series: 1-41. New York, Oxford: Berghahn Books.

Klumbyte, Neringa. 2008. The Post-Soviet Publics and Nostalgia for Soviet Times, I. W. Schröder, A. Vonderau (eds). Changing Economies and Changing Identities in Postsocialist Eastern Europe. Halle Studies in the Anthropology of Eurasia 20: 27-45. Berlin: LIT Verlag. 
Lietuvos apskritys: ekonomine ir socialine raida. 1996, 1999. Vilnius: Statistikos departamentas prie Lietuvos Respublikos Vyriausybės.

Lietuvos gyventojai. 2019, Oficialiosios statistikos portalas. Lietuvos statistikos departamentas. <https://osp.stat.gov.lt/documents/10180/6717512/LIETUVOS+ GYVENTOJAI+2018_\%282019_leidimas\%29_.pdf/e1550b89-ab0b-4f04-9aa4778223a6e3f6> [žiūrèta 202009 17].

Lietuvos Respublikos Vyriausybės ir Lenkijos Respublikos Vyriausybės sutartis dèl bevizinio važiavimo. 1993, e-seimas.lrs.lt. <https://e-seimas.lrs.lt/portal/ legalAct/lt/TAD/TAIS.11158> [žiūrèta 202007 15].

Lietuvos socialiné raida 1990 metais. 1991. Vilnius: Informacinis-leidybinis centras.

Long, Norman. 2005. Exploring Local/Global Transformations: A View from Anthropology, A. Arce, N. Long (eds). Anthropology, Development and Modernities: Exploring Discourses, Counter-Tendencies and Violence: 183-199. New York: Routledge.

Low, Kelvin E. Y. 2015. The Sensuous City: Sensory Methodologies in Urban Ethnographic Research, Ethnography 16(3): 295-312.

Marijampolès miesto šventę minint. 2016, Oficialiosios statistikos portalas 05 27. Lietuvos statistikos departamentas. <https://osp.stat.gov.lt/informaciniaipranesimai?eventId=137649> [žiūrèta 202004 04].

Narotzky, Susana. 2015. The Payoff of Love and the Traffic of Favours: Reciprocity, Social Capital, and the Blurring of Value Realms in Flexible Capitalism, J. Kjaerulff (ed.). Flexible Capitalism: Exchange and Ambiguity at Work. EASA Series: 268-310. New York, Oxford: Berghahn Books.

Narotzky, Susana. 2018. Rethinking the Concept of Labour, Journal of the Royal Anthropological Institute 24(S1): 29-43.

Nielsen, Finn Sivert. 2006. They Eye of the Whirlwind: Russian Identity and Soviet Nation-Building. Quests for Meaning in a Soviet Metropolis. <http://www.anthrobase.com/Txt/N/Nielsen_F_S_03.htm> [žiūrèta 202004 04].

Parry, Jonathan. 2018. Introduction: Precarity, Class, and the Neoliberal Subject, C. Hann, J. Parry (eds). Industrial Labor on the Margins of Capitalism: Precarity, Class, and the Neoliberal Subject: Max Planck Studies in Anthropology and Economy 4: 1-38. New York, Oxford: Berghahn Books.

Pine, Frances. 2014. Migration as Hope: Space, Time, and Imagining the Future, Current Anthropology 55(S9): S95-S104.

Plattner, Stuart. 1989. Marxism, S. Plattner (eds). Economic Anthropology: 379396. Stanford: Stanford University Press.

Portes, Alejandro; Walton, John. 1981. Labor, Class, and the International System. Studies in Social Discontinuity. New York: Academic Press.

Sampson, Steven L. 1987. The Second Economy of the Soviet Union and Eastern Europe, The Annals of the American Academy of Political and Social Science 493: 120-136. 
Shlapentokh, Vladimir. 1989. Public and Private Life of the Soviet People: Changing Values in Post-Stalin Russia. New York: Oxford University Press.

Smith, Estellie M. 1989. The Informal Economy, S. Plattner (ed.). Economic Anthropology: 292-317. Stanford: Stanford University press.

Strangleman, Tim. 2007. The Nostalgia for Permanence at Work? The End of Work and its Commentators, The Sociological Review 55(1): 81-103.

Strümpell, Christian. 2017. The Anthropology of Work and Labour: Editorial Note, EthnoScripts: Zeitschrift für aktuelle ethnologische Studien 19(2): 5-14.

Subačius, Kęstutis. 2009. Marijampolès miestas: priešistorè, miesto ištakos, istorija, mintys, küréjai. Marijampolè: Piko valanda.

Šliavaitè, Kristina. 2003. Tarp rizikos ir saugumo: požiūriai į atominę jègainę ir bedarbystės grèsmę Visagine, Lietuvos etnologija: socialinés antropologijos ir etnologijos studijos 3(12): 79-112.

Šliavaitè, Kristina. 2010. Deindustrializacija, socialinis nesaugumas ir išgyvenimo strategijos posovietineje erdveje: Visagino atvejis, Lietuvos etnologija: socialinés antropologijos ir etnologijos studijos 10(19): 93-116.

Tranavičiūtè, Brigita. 2012. Sovietinès visuomenès verslumo formos ir priežastys XX a. pabaigoje Kauno mieste, Acta humanitarica universitatis Saulensis 14: 305-313.

Verdery, Katherine. 1996. What Was Socialism, and What Comes Next? Princeton Studies in Culture / Power / History. Princeton, New Jersey: Princeton University Press.

Walley, Christine J. 2013. Exit Zero: Family and Class in Postindustrial Chicago. Chicago, London: The University of Chicago Press.

Wunderlich, Filipa Matos. 2008. Walking and Rythmicity: Sensing Urban Space, Journal of Urban Design 13(1): 125-139.

\section{'Everyone Wants their Own Business': Post-Soviet Deindustrialisation, Work and Means of Livelihood in Marijampole}

\section{Aušra Teleiš̀}

\section{Summary}

The political processes in the reconstruction of statehood and the restructuring of the economy resulted in deindustrialisation, which led to a work crisis: the loss of jobs, unemployment, and non-payment or low incomes in cities in Lithuania. The paper asks how residents of Marijampolè, a former Soviet industrial 
centre, made a living during the work crisis, and what means of livelihood were developed in order to make a living or improve their economic well-being. The paper analyses the transformation of the city of Marijampole, by presenting a view of today's Kaunas Street; the beginnings of self-employment; aspects of how livelihoods were developed and formalised; how new workplaces were created; and changes in the conception of work. The paper is based on fieldwork carried out in Marijampole from November 2018 to December 2019. In order to get to know Marijampole and the cultural processes in it, walking ethnography and interviews with industrial workers, as well as with workers in other fields, were performed. It should be emphasised that people who were not directly involved in the activities of industrial enterprises also faced the challenges of deindustrialisation.

The sight of Kaunas Street, abandoned industrial buildings, kiosks, small shops, supermarkets and various companies involved in car sales, shows the diversity of work activities and workplaces, as well as the fragmentation of industry in Marijampolè. The transformation of places in Marijampole represents means of livelihood: trading and various services. The article further analyses human actions that were practised during the work crisis. It reveals three ways self-employment was started. First, self-employment was initiated by adapting formal work practices that were performed in Soviet times. Second, individual work activities were a continuation of late Soviet-era entrepreneurship and informal activities, such as driving to other countries to engage in trade. Third, the use of personal connections. The paper reveals that self-employment was started not by the activation of social connections of owners of kiosks or car sellers, but rather by receiving suggestions from friends, family members or colleagues. It is emphasised that the activity or entrepreneurship itself has the ability to involve other people.

Local entrepreneurship and work activities created conditions for the development of alternative economic practices. This situation created the common business of mašininiai. This is understood as collective involvement in activities related to car dealing. The article highlights that the creation of new workplaces and the expansion of business was made based on work experience, and entrepreneurial and work logic. As the business expanded, a new structure emerged. In this case, another person is employed and receives a fixed salary, and the founder of the business becomes a person who employs others. These processes and the legalisation of informal work activities were factors which determined that means of livelihood became formal jobs and a part of everyday life in Marijampole.

The article also emphasises that self-employment is conceptualised as 'business', which is associated with long-term activities, active actions to create per- 
sonal financial well-being, cleverness, and the ability to take advantage of opportunities. The concept of 'business' includes the activity itself: trade or the provision of services, and the ownership of property. 'Business' can also indicate the field of interrelated activities. The article reveals that a means of livelihood is conceptualised as more than self-employment. It connects the active creation of a workplace, individual work activities and ownership.

To conclude, the article stresses that various means of livelihood, individual activity, and the tendency of business to expand and grow were a way of making a living through the work crisis that was caused by deindustrialisation. These aspects and the common business of mašininiai created a new social and economic structure in Marijampolè, which produced the conditions for creating new jobs and involving personal connections. The work crisis was dealt with by creating workplaces outside industrial enterprises. 